\title{
Fictionis. A synthetic introduction into the mythology of transmission*
}

Mihai Șleahtițchi

Mihai Şleahtițchi - Docteur d'état in social psychology, $\mathrm{PhD}$ in general psychology, $\mathrm{PhD}$ in the theory and history of paedagogy, Khisinew, Republic of Moldova

\begin{abstract}
Often, current literature ${ }^{1}$ associates the phenomenon of socio-cultural transmission ${ }^{2}$ with an "awakening gift". Developing "at all levels and at all ages of our lives" for perpetuating virtuous existential models, this phenomenon "triggers new emotions and cognitive states in us, determines us to live an unusual experience, to acquire new knowledge, values, identities or cultures".

As an "awakening gift", socio-cultural transmission is undoubtedly a source of change "for both the giver and the receiver". What comes from those "at one end of the relation" is imposed by the ability to substantially influence "the life of those at the other end of the bond". Ultimately, the type targeted by transmission can be associated with a stimulating factor, likely to induce social actors to give and receive really interesting, notable and essential "important things". Since socio-cultural transmission, bearing such an "awakening gift" aura, reproduces a phenomenon of enormous scope and depth that goes beyond the ordinary measure, it is absolutely natural for people, interested by the nature and the ways of its manifestation, to offer different points of view. Some of them are sufficiently well- structured and convincing, based on logical principles. Others, however, lack consistency and clarity, which places us, whether we want it or not, under the domination of confusion. Having no real basis, the latter appears, most often, as exaggerated appraisals or simplistic representations, that is under the form of false interpretive clues or - more precisely - of elementary myths of phenomenological expression. Considering this last reason, the present study refers to three mythical constructions, which obviously distort the entity of the phenomenon of socio-cultural transmission. These are the assessments according to which (i) "all people are experts in transmission", (ii) "transmission is good in itself" and (iii) "transmission means communication".
\end{abstract}

\footnotetext{
"The present study, entitled "Authenitc transmission. "The awakening gift», between myth and reality", has been communicated at the interdisciplinary Colloquy"Faith. Culture. Transmission" organized at Putna Monastery, Romania, August 22-25 2019.
} 


\section{Transmission, communication, myth, mythology.}

Often, specialized sources ${ }^{1}$ associate the phenomenon of socio-cultural transmission ${ }^{2}$ with an "awakening gift". Developing "at all levels and at all ages of our lives" for perpetuating virtuous existential models, this phenomenon "triggers new emotions and cognitive states in us, determines us to live an unusual experience, to acquire new knowledge, values, identities or cultures".

As an "awakening gift", socio-cultural transmission is undoubtedly a source of change "for both the giver and the receiver". What comes from those "at one end of the bond" is imposed by the ability to substantially influence "the life of those at the other end of the bond". Ultimately, the type targeted by transmission can be associated with a stimulating factor, likely to induce social actors to give and receive really interesting, notable and essential "important things".

Since socio-cultural transmission, bearing such an "awakening gift" aura, reproduces a phenomenon of enormous scope and depth that goes beyond the ordinary measure, it is absolutely natural for people, interested by the nature and ways of its manifestation, to offer different points of view. Some of them are sufficiently well-structured and convincing, based on logical principles. Others, however, lack consistency and clarity, which places us, whether we want it or not, under the domination of confusion. Having no real basis, the latter appears, most often, as exaggerated appraisals or simplistic representations, that is under the form of false interpretive clues or - more precisely - of elementary myths of phenomenological expression.
Considering this last reason, the present study refers to three mythical constructions, which obviously distort the entity of the phenomenon of socio-cultural transmission. These are the assessments according to which (i) "all people are experts in transmission", (ii) "transmission is good in itself" and (iii) "transmission means communication".

\section{MYTH NO. 1: ALL PEOPLE ARE EXPERTS IN TRANSMISSION}

It goes beyond saying that any social actor can transmit, in one form or another, ideas, opinions, attitudes, emotions, values or/and beliefs. The introductory part of the collective volume entitled "Transmission. What we offer to one another", translated into Romanian and published, in 2018, at"Spandugino" Publishing House in Bucharest provides the following fragment:

„Transmission involves us all: along the time, it entangled us in the long, intricate chain made up of the men and women who had lived before us, and also our contemporaries, who live together with us. We inherited their experience, their culture, their values. In our turn, we transmit to our children, our parents, our friends and to all those living around us our knowledge, our competences and our specific mode of living. Transmission occurs at all levels and all ages of our individual and collective lives" (1).

More than that, considering the basic content of the here-mentioned volume, some authors - special mention being made of C. Lesire, I. Kotsou and Ch. André (2) - come up with the idea according to which people represent a species capable of transmitting. Or, according to them, transmission assumes a "trajectory 
issued by the motivation of sharing with all our human fellows something of value, something we had ourselves received". Starting from this trajectory, we finally come to build up our lives, to orient our destinies and to act upon the society in which we live.

Even if the data we employed up to now shows that transmission involves us all or - in other words - it is to be found in each one's life, the observation to be made is that, still, this does not allow us to confer to each homosapiens the attribute of a person capable of transmitting or - in a more powerful form of being an expert in strategies and techniques of transmitting something to someone. In the already mentioned collective study about the entity and manifestation forms of the transmission phenomenon, one may find a whole series of fragments in which, by various combinations of words, such a state-of-the-art is fully acknowledged. Here are only a few illustrative examples:

- „ (...) however, in very many cases, we are not aware of what the transmission process has in store for us" (3);

- $\quad,(.$.$) along most part of the time,$ we do transmit without knowing it, by means of attitudes and emotions" (4);

- „, (..) apart from the contents we want to share to our children or to those close to us, we also transmit a manner of functioning, of getting attached to the others, a manner of either integrating or trespassing interdictions even if, in many situations, we are not aware of this" (5).

It is therefore obvious that acquiring the experience of transmission does not mean that one becomes an expert in transmission. $\mathrm{K}$.
Floyd, professor of communication at Arizona State University, author of the well-known volumes Interpersonal Communication (2011), Communicating Affection: Interpersonal Behavior and Social Context (2008) and Communication Matters (2010), has provided a set of explanations, which match entirely with our intentions, namely:

- Many people drive cars, which does not mean that they are expert drivers;

- Many people have children, which does not make them experts in parenting;

- Many people communicate, which does not transform them in specialists in communication (6).

Undoubtedly, in the field of transmission, personal experience is extremely important, however, being an expert assumes acquiring of training which goes far beyond its limits. Being an expert in transmission actually means having in-depth studies in this extremely complicated domain (7) and, equally a high level of understanding of such a phenomenon, which most of them do not master or hardly comprehend (8).

\section{MYTH NO. 2: TRANSMISSION IN ITSELF IS GOOD}

Once again, drawing inspiration from the work of K. Floyd (9), we dare make a comparison between transmission and money. Or, considering transmission as good in itself is equivalent to believing that money is good in itself, as well. Indeed, in numerous situations, money may be viewed as having a positive role, a value based on expertise and necessity, a notion bearing a beneficial utilization (such as, for example, payment of study fees or the expenses involved for medical care, buying a house or donations to an asylum for elderly people or for orphan 
\%

children). Equally numerous are also the cases in which money may be approached from a strictly negative perception (such as, for example, the illicit theft of money, disposing of the financial reserves from the banking system, financing terrorist groups, bribing actions in the judiciary, educational or medical system or counterfeit auctions in public acquisitions). In any of these cases, one may observe that it is not the money that is good or bad, but the modality of its being used.

The same idea applies to transmission, as well, once it may be used not only for good actions (such as, for example, when transmitting to our children, friends or persons close to us elevated behavioural patterns), but also in detrimental activities (such as the situations in which we mislead a person or recognize that the information we provide for them actually represents stereotypes and preconceived ideas). Being convinced that such an attitude is a perfectly natural one, some specialists in transmission do not hesitate to evidence and value it. See, as an illustration, the assertions made by C.Lesire, I. Kotsou and Ch. André (10):

"As many other processes, transmission has several aspects: it may be both positive and negative. One can transmit honest behaviours and patterns, as well as destructive ideas. Crushing ideologies, hate, greed, endless competition, selfishness are also transmitted. Equally, an unsolved traumatic experience is liable to transmisssion, sometimes along several generations. Modern epigenetic studies demonstrate that this type of experience may modify the genetic expression of our children, even if they had not been directly faced such a situation".
Even if, in most of cases, the literature of the field discusses mainly the "bright aspects" of transmission (11), this does not demonstrate that some "dark aspects" do not exist or that they might not manifest themselves in a certain moment of time. By no means, this does not imply that transmission is good or bad, but only that the manner of its application may be not the correct one.

\section{MYTH NO. 3: TRANSMISSION IS COMMUNICATION}

By the manner of its manifestation, transmission appears as an organic element of the general equation of communication. As a general rule, one of the first ideas to be considered is that no difference does really exist among the processes here under investigation. Indeed, both transmission and communication reproduce, in a functional manner, a mechanism by means of which people share ideas, predictions, suggestions and feelings. More than that, both transmission and communication are dynamically identical. Or, both situations assume a social interaction realized by means of symbols, which illustrate the trend through which people generate interpretative systems, obtain, transform and make use of information necessary for going on with their lives. Similarly, communication, transmission eminently represents a continuously changing, a most active and mutual process (12).

Even if, apparently, the verbs "to transmit" and "to communicate" are semantically identical, things differ in everyday life. In other words, although, at first sight, transmission is wholly part of the general equation of the communication process, it cannot be in any way confused with it. To support such an interpretation, at least three arguments may be provided. Firstly, one should recognize that, frequently, "we do communicate enormously yet without 
transmitting something fundamental to the others" (13). More than that, it is equally true that, in too many situations, "we ardently do wish to communicate something, yet we are transmitting only the opposite". The power of the second argument may be explained as follows: "while communication contributes to transporting an information in space, transmission permits sharing some content in time, along a duration which goes beyond us, and also beyond the receiver". Finally, in relation with the third argument, mention should be made of the manner in which the two phenomena react to the surrounding reality: if communication "gets adjusted to our foolish rhythms (if such be the case, it gets adjusted to simultaneity and rapidity)", then transmission "requires slowness, continuity, connection".

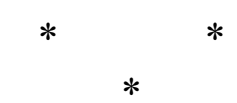

It goes without saying that the abovediscussed myths provide "a communication system, a message, a significance" (14). With the variants in which they are delivered, they distort the truth, appearing as "metaphysical speculations", namely as some "imaginary stories bearing figurative meaning, and lacking any rational, real discursivity" (15).

Messages of the type "Everyone is an expert in transmission", "Transmission in itself is good" or "Transmission means communication" demonstrate that the magic force of myth remains and will always remain an implacable existential datum. If ancient thinkers used to bring to good account some immemorial incentives, the modern and postmodern ones prefer not only new themes, but also a concrete manner of representing a secondary mythology. In spite of the fact that they consider themselves as being better educated and much more cultivated than their predecessors, people of today accept to be devoured by myths or, to cite Lucian Blaga, prefer to live, without being aware of this, in a passionate manner, in a permanent mythic atmosphere (16). Even if the domain of rational thinking is constantly extending, according to E. Cassirer (17), nowadays, people always resort - in their practical and social life - to the primitive stages of human culture, and surrender when confronted with metaphysical speculations, which means that, ultimately, the mythical monsters have not yet been defeated, being instead involved in the creation of a new, incredible universe (18). In the myths of transmission - as, in fact, in all other contemporary myths (especially those which illustrate the alienation of human beings, assailed by the artificial images created by the new informational technologies, the importance gained by the automobile, by mobile phones or by washing powders) - the traditionally sacred element is absent. In our opinion - a perfectly natural condition. As a matter of fact, the evolution in such a direction was expected, indeed. Or, as mentioned in numerous situations (19), from one stage to another or from one ideology to another, science and technology, nation, race, sex, "the new society" and "the bright future" have been, each at its time, sacralized (which actually involved desacralization of the recurrent themes). Apart from this, one should observe that, in fact, desacralization of the recurrent themes changed nothing: along with the reflux of religious faiths and practices, the idea of sacredness does not disappear in modern and post-modern epochs, because a human being "must believe in something, in a superior reality, the only one capable of rendering significance to the world and to human condition" (20). Numerous and extremely diverse, the new social phenomena and facts bring about some dissipation of sacredness, thus confronting us with a "reversed religion". In other words, the old sacred entity changes its form, acquiring 


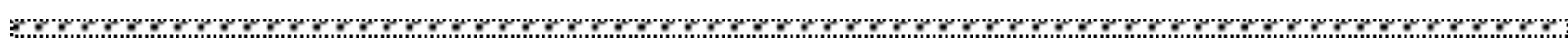
unexpected valences, gets "reconverted", myths of transmission will still continue to which demonstrates that the human being is represent the expression of some distorted capable of "transfiguring anything in interpretative models, codifying, in a specific religion". manner, the perceptions referring to "what we

As a matter of fact, even if leaving aside the exponential images of the "primordial time" bring to the others" in an extremely accessible and easy-to-transmit form.

or if neglecting traditional sacredness, the

\section{ACKNOWLEDGEMENTS AND DISCLOSURES}

The authors state that they are no declared conflicts of interest regarding this paper

\section{REFERENCES AND NOTES}

1. Alvarez, C., André, Ch., Gueguen, C. et al. Transmiterea. Despre ce ne aducem unii altora. Translated from French by Doina Jela, București, Spandugino Publishing House, 2018, p. 9. ISBN 978-606-8944-20-3

2. Lesire, C., Kotsou, I., André, Ch. Ce înseamnă a transmite? In: C. Alvarez, Ch. André, C. Gueguen et al. Transmiterea. Despre ce ne aducem unii altora, Translated from French by Doina Jela, București, Spandugino Publishing House 2018, p. 14. ISBN 978-606-8944-20-3

3. Alvarez, C. Introducere. În: C. Alvares, Ch. André, C. Gueguen et al. Transmiterea, despre ce ne aducem unii altora, Translated from French by Doina Jela, București, Spandugino Publishing House 2018, p. 9. ISBN 978-6068944-20-3

4. Ibidem, p. 10 .

5. Lesire, C., Kotsou, I., André, Ch. Ce înseamnă a transmite? In: C. Alvarez, Ch. André, C. Gueguen et al. Transmiterea. Despre ce ne aducem unii altora, Translated from French by Doina Jela, București, Spandugino Publishing House 2018, p. 15. ISBN 978-606-8944-20-3

6. Floyd,K. Interpersonal Communication, Second Edition, New York, McGraw-Hill Education, 2011, p. 39.

7. With reference to the complex character of the transmission phenomenon, C. Alvarez, I. Kotsou and Ch. André feel themselves obliged to intervene with the following observation: "Some of the persons who act continously for leaving behind them a more interdependent and long-lasting world get discouraged when understanding the amplitude of the task they assumed. This aspect should seriously draw our attention as to our responsibilities and to give us hope when we lose our enthusiasm".

See, in this respect, Lesire, C., Kotsou, I., André Ch. Ce înseamnă a transmite? In: C. Alvarez, Ch. André, C. Gueguen et al. Transmiterea. Despre ce ne aducem unii altora, Translated from French by Doina Jela, București, Spandugino Publishing House 2018, p. 32. ISBN 978-606-8944-20-3

8. For interested readers, we shall sketch a possible profile of the expert in transmission. At large, as one may conclude from the analysis of the observations and assertions presented by various sources, such a profile may appear as a variant of an operational aggregate including at least eleven abilities (the term referring to, as generally known, to "the possibility of working in some domain, of achieving something"):

- The capacity of transmitting in a friendly and largely-argumented manner (or, "any transmission performed for a good scope, justified, with love and goodwill, is much more efficient than the one performed with either indiference or with an uncorrect scope for the other part"; one should necessarily "pay attention to the manner in which we transmit and to permanently ask questions about our deep motivations, so that to have an as correct as possible transmission");

- The capacity of an articulated transmission (or, "an efficient transmission involves coherence, expressed mainly in the manner of approaching the others, of stressing and valorizing our ideas");

- The capacity of approaching, with equal responsibility "both the content of what is transmitted", and "the manner of transmitting" ( in the opinion of E. Maex, one of the most appreciated Belgian psychiatrists, people learn to respect when they are treated with respect. According to him, "transmission means attitude: if we want to transmit something, the question to be asked is simple - how should we behave in such a situation? Do we pay respect to the others, to the environment, to life, or do we only preach respect? In the former case, respect is present, in the latter, it is only the sermon");

- The capacity of presenting the essential part of what is to be transmitted (or, when aiming at positively influencing the pnes around us, it is extremely important that the agent of this type of influence "should 

embody the chief point of what is being transmitted or will be soon transmitted"; in this way, "transmission includes exemples and coherence, as well as the emulation produced by the behaviours we admire");

- The capacity of being receptive ("transmission is an action requiring to listen to and to undestand the one to whom you transmit"), of having a sound mind concentrată ("transmission equies paying attention to the world around you"), of being perseverent ("the process of transmission involves esentially effort, patience, time offered to the other to act at its own pace");

- The capacity of generating effects of emotional contagiousness (an expert in transmission should have the ability to become attached to the others, continously transmitting to them beneficial emotions and affective states; if he is receptive and mindful, in his turn, the transmitter "will receive a lot from those around him");

- The capacity of being sympathetic both affectively (once, in transmission, "to feel and to share the emotion of another person, yet without confusing one' sown ego with the ego of the other fellow" is extremely important) and cognitively (as authentic transmission assumes "understanding of the emotions and thoughts of the other");

- The capacity of valorizing the age and individual peculiarities of the persons you contact ("to transmit means to ask questions about what is it correct to say, to do, to demonstarte, on considering the age and individuality of the person we are addressing to");

- The capacity of "giving" and of "receiving" not only by word of mouth, but also in a non-verbal manner ("transmission is performed even by the most harmless behaviour of ours - a manner of looking at, a smile, a hand stretch out to another; "if you utter something, yet your body, your sight transmit a different thing, the interlocutor will be marked by this last signs");

- The capacity continuous self-improvement in the science and art of transmission (extremely important being that "the transmiter should ceaselessly transform himself/herself for better serving the one to whom he/she transmits, thus contributing to the creation of a new world");

- The capacity of inventing and of applying new transmission patterns (as the crises periodically manifested against the background of vaious social turbulences and which, in one form or another, influence transmission, "assume some sustematic reevaluations of the common manner of developing a relation between the giver and the receiver").

See, in this respect, for some other other details, Alvarez, C. Crearea unui context favorabil transmiterii. In: C. Alvares, Ch. André, C. Gueguen et al. Transmiterea. Despre ce ne aducem unii altora, Translated from French by Doina Jela, București, Spandugino Publishing House 2018, p. 61-87 ISBN 978-606-8944-20-3; Bègue, L. Psychologie du bien et du mal, Paris, Odile Jakob, 2011; Christakis, N.A., Fowler, J. H. Social contagion theory: Examining dynamic social networks and human behavior. In: Statistics in Medicine, 2013, no. 32 (4), p. 556-577; Gueguen, C. Copilăria: o etapă-cheie în procesul de transmitere. In: C. Alvarez, Ch. André, C. Gueguen et al. Transmiterea. Despre ce ne aducem unii altora, Translated from French by Doina Jela, București, Spandugino Publishing House 2018, p. 3559 ISBN 978-606-8944-20-3; Lahaye, W., Pourtois, J.-P., Desmet, H. Transmettre. D'une génération à l'autre, Paris, P.U.F., 2007; Lenoir, F. A transmite cheile devenirii de sine. In: C. Alvarez, Ch. André, C. Gueguen et al. Transmiterea. Despre ce ne aducem unii altora, Translated from French by Doina Jela, București, Spandugino Publishing House 2018, p. 89-113 ISBN 978-606-8944-20-3; Lesire, C., Kotsou, I., André, Ch. Ce înseamnă a transmite? In: C. Alvarez, Ch. André, C. Gueguen et al. Transmiterea. Despre ce ne aducem unii altora, Translated from French by Doina Jela, București, Spandugino Publishing House 2018, p. 15-33 ISBN 978-606-8944-20-3; Lesire, C., Kotsou, I., André, Ch. Moștenirea unei lumi mai solidare și mai durabile. In: C. Alvarez, Ch. André, C. Gueguen et al. Transmiterea. Despre ce ne aducem unii altora, Translated from French by Doina Jela, București, Spandugino Publishing House 2018, p. 153181 ISBN 978-606-8944-20-3; Lopez, F. Ce au să ne transmită popoarele de la celălalt capăt al lumii. In: C. Alvarez, Ch. André, C. Gueguen et al. Transmiterea. Despre ce ne aducem unii altora, Translated from French by Doina Jela, București, Spandugino Publishing House 2018, p. 131-151 ISBN 978-606-8944-20-3; Maex, E. Leven in de maalstroom, www.levenindemaalstroom.be/nl/blog/wat-transmissie; Petit, M. Lire le monde: expériences de transmission culturelle aujourd' hui, Paris, Belin, 2014; Ricard, M. Plaidouyer pour l' alruisme. La force de la bienveillance, Paris, Nil, 2013, p. 78-81; Ricard, M. Transmiterea spirituală: atunci când mesagerul este el însuși mesajul. In: C. Alvarez, Ch. André, C. Gueguen et al. Transmiterea. Despre ce ne aducem unii altora, Translated from French by Doina Jela, București, Spandugino Publishing House 2018, p. 115-129 ISBN 978-606-8944-20-3 or/and Vahanian, G. Transmission et tradition. Autres temps. In: Cahiers d'éthique sociale et politique, 1995, no.48, p. 6-11.

9. Op. cit., p. 40.

10. Lesire, C., Kotsou, I., André, Ch. Ce înseamnă a transmite? In: C. Alvarez, Ch. André, C. Gueguen et al. Transmiterea. Despre ce ne aducem unii altora, Translated from French by Doina Jela, București, Spandugino Publishing House 2018, p. 25-26 ISBN 978-606-8944-20-3. 
ндн 11. An illustrative example in this respect is offered by the same C. Lesire, I. Kotsou and Ch. André who, discussing the principles applied for the elaboration of one of their most famous co-authored work (the study entitled "Ce înseamnă a transmite?"), are forced to observe the following facts: "In this paper, inspired by positive psychology, we deliberately chose to concentrate our efforts mainly on the bright aspects of transmission, on the factors upon which we can act". See, in this respect Lesire, C., Kotsou I., André, Ch. Ce inseamnă a transmite? In: C. Alvarez, Ch. André, C. Gueguen et al. Transmiterea. Despre ce ne aducem unii altora, Translated from French by Doina Jela, București, Spandugino Publishing House 2018, p. 26. ISBN 978-606-8944-20-3.

12. The similitudes here considered are to be found - in various forms - in several specialized studies, published, in time, both in the Romanian space and outside it. Among them, mention should be made of: Baron, R. Behavior in Organization, New York, Allyn and Bacon Inc., 1983; Baylon, C., Mignot, X. La communication, Paris, Nathan, 1999; DeVito, J. Human communication, New York, Harper \& Row Inc., 1988; Dinu, M. Comunicarea: repere fundamentale, București, The Scientific Publishing House 1997; Hubels, S., Weaver, P. Communicating Effectively, New York, Random House, 1986; Miège, B. Societatea cucerită de comunicare, Iași, Polirom Publishing House 2000; Pănișoară, I.-O. Comunicarea eficientă, Ivth edition, Iași, Polirom Publishing House 2015; Ramonet, I. Tirania comunicării, București, Doina Publishing House 2000; Roberts, K., Hunt, D. Organizational Behavior, New York, PWS-Kent Publishing Company, 1991; Ross, R. Speech communication, New Jersey, Prentice-Hall, 1986; Şoitu, L. Pedagogia comunicării, București, The Didactic and Pedagogic Publishing House, 1997 sau/și Stanton, N. Comunicarea, București, Scientific and Technical Publishing House, 1995.

13. In this context, we shall consider certain formulations taken over from the studies of three authors - again, C. Lesire, I. Kotsou and Ch. André - who repeatedly and firmly asserted that transmission is different from communication. See, in this respect, Lesire, C., Kotsou, I., André, Ch. Ce înseamnă a transmite? In: C. Alvarez, Ch. André, C. Gueguen et al. Transmiterea. Despre ce ne aducem unii altora, Translated from French by Doina Jela, București, Spandugino Publishing House 2018, p. 27-29. ISBN 978-606-8944-20-3.

14. The formulation is taken over from R. Barthes, whose idea - namely that any myth, whichever the time of its creation, "is a communication system, a message, it is equally speaking, a manner of offering significance, a form" - we share. Again agreeing with him, we consider that "significance is the myth itsels, with a linear extension in the case of oral myths and with a multidimensional extension, respectively, in the case of the visual myth". For additional details, see Barthes, R. Mitologii, Translated by Maria Carpov, Iaşi, European Institute Publishing House 1997, p. 235. ISBN 973-586-055-4

15. As known, the initiative of operating with "metaphysical speculations" belongs to J. J. Wunenburger, the reputed French philosopher specialized in image and sacredness. According to this epistemological approach, the myth appears as "an imaginary story bearing figurative significance, lacking any rational discursivity and reality"and equally as "a reliable intellectual practice, when making speculations about the very meaning of life or of the world, considered in absolute and taken as a whole". See also Wunenburger, J. J. Filosofia imaginilor, Translated from French by Muguraș Constantinescu, Iaşi, Polirom Publishing House 2004, p. 297-298. ISBN 973-681-256-1

16. Blaga, L. Despre mituri. In: L. Blaga, D. Ghișe. Trilogia culturii. Orizont și stil. Spațiul mioritic. Geneza metaforei și sensul culturii, București, Publishing House for Literature, 1969, p. 300.

17. Cassirer, E. Mitul statului, Iași, European Institute Publishing House, 2001, p. 23-24. ISBN

16. 973-61-1178-4

18. Ibidem, p. 364.

19. See, for example, Boia, L. Pentru o istorie a imaginarului, București, Humanitas Publishing House, 2000, p. 2629. ISBN 973-50-0042-3

20. The expression is taken over from Boia, L. Pentru o istorie a imaginarului, București, Humanitas Publishing House, 2000, p. 74. ISBN 973-50-0042-3.

\section{Corespondence:}

Mihai Șleahtițchi,

Docteur d'état in social psychology, $\mathrm{PhD}$ in general psychology, $\mathrm{PhD}$ in the theory and history of paedagogy, Khisinew, Republic of Moldova 